\title{
Criminal organizations and resilience
}

\author{
Julie Ayling* \\ Australian Research Council Centre of Excellence in Policing and Security, Regulatory Institutions Network Building 8 , \\ Australian National University, Canberra ACT 0200, Australia
}

\begin{abstract}
Criminal organizations inhabit dynamic environments where the pressures of competition and state opposition constantly challenge their existence. To survive and prosper, they must be resilient. Little has been written about the concept of resilience in the context of illicit organizations. This article explores possible sources of resilience for criminal organizations, focusing on institutionalised gangs. Drawing on ecological and organizational literature, resilience is defined as the capacity to absorb and withstand disruption and to adapt to change when necessary. For gangs and other criminal organizations, sources of resilience may include environmental factors and individual organizational features such as network characteristics. Resilience is not just a concept that enables criminologists to better understand the longevity of some criminal organizations; it also has implications for the strategic and operational aspects of policing such organizations, including intelligence gathering, the design of interventions and assessment of their potential unintended consequences.
\end{abstract}

(c) 2009 Elsevier Ltd. All rights reserved.

\section{Introduction}

Criminal organizations inhabit dynamic environments where the pressures of competition and state opposition constantly challenge their very existence. To survive and prosper, they must be sufficiently resilient to adapt to changing conditions arising from new competition, alterations in laws, policies and law enforcement practices, expansion or contraction of illegal markets and the availability of new technologies. Change may also result from internal conflicts: the organization may splinter, merge with other groups or reorganize (Weisel, 2002a).

* Tel.: +61 26125 6035; fax: +6126125 1507.

E-mail address: julie.ayling@anu.edu.au 
While the study of criminal organizations has not entirely overlooked resilience (see, for example, Williams, 2001; Kenney, 2006, 2007; Jackson, 2006; Bouchard, 2007), little attention has been paid to how resilience in criminal organizations develops. What is it about criminal organizations that have survived and flourished amid constant threat and frequent confrontation that has given them the resilience to do so?

The nature and sources of resilience have been much discussed in some non-criminal justice domains. In this article, we use ecological, organizational as well as criminological literature to draw out sources of resilience that may be shared by different types of illicit organizations, using gangs as the focus. Non-criminological orthodoxies are used judiciously to inform discussion, and the unique features of criminal organizations are taken into account.

Sections 2 and 3 of the article explore the concept of resilience in ecological and organizational studies. Based on that literature, in section 4 a concept of resilience is adopted for the purpose of the article that includes both the capacity to withstand disruption and adaptive capacity when circumstances change. In section 5, we consider whether the characteristics of licit resilient organizations identified in section 3 are applicable as a whole to criminal organizations, and conclude that the latter's illegal status significantly affects their resilience capacity.

The focus then turns to gangs. Section 6 explores the appropriateness of using gangs to illustrate the resilience of criminal organizations. Then in sections 7 and 8, possible sources of that resilience are examined, drawing on examples from various jurisdictions. The article concludes with some general thoughts on how a resilience perspective is not only a useful construct for academics but also could improve strategic and operational law enforcement approaches to gangs and other criminal organizations.

Some terminology used in this article should be clarified. We draw upon literature relating to both or either of "organizations" and "networks". While all organizations are networks in the broadest sense of that term, ${ }^{1}$ networks are also commonly regarded as particular forms of criminal organizing where linkages among actors (whether individuals or organizations) are predominantly lateral or horizontal, in contrast to the mainly vertical configuration of hierarchies. Characteristics arising from this horizontal configuration - network characteristics bestow certain advantages on organizations that are relevant to their resilience, and these are identified in the second half of the article.

\section{The concept of resilience in ecology}

The word 'resilience' is derived from the Latin resilio (resilíre), meaning "to jump back" (Templeman and Bergin, 2008). It was first used in physics and mathematics to describe the ability of certain materials to resume their shape after displacement (Norris et al., 2008). Due to climate change, the resilience and sustainability of socio-ecological systems has become a 'hot' topic, but the ecological concept of resilience was actually introduced by C.S. Holling (1961) over forty years ago. ${ }^{2}$ Resilience relates to the stability of systems: their ability to absorb disturbance and reorganize while undergoing change so as to retain the same function, structure, identity and feedbacks (Walker et al., 2004: 6). A condensed version of ecological resilience thinking follows, sufficient for current purposes.

\footnotetext{
${ }^{1}$ Nohria (1992: 4) defines a network as "a set of nodes (e.g. persons, organizations) linked by a set of social relationships (e.g. friendship, transfer of funds, overlapping membership) of a specified type".

${ }^{2}$ For an overview of the emergence of the resilience perspective, see Folke, 2006.
} 
Within the concept of resilience are two different but related meanings (Gunderson, 2000). The first is "engineering resilience", which assumes that a single or global equilibrium, or steady state, exists to which a disturbed system will return, measured as the time this process takes. More commonly prevailing, and used in this article, is a second meaning that allows for evolution in systems and an element of unpredictability in their behaviour. "Ecological resilience" recognises that systems can exist in multiple steady states. A system subjected to sufficient disturbance can move from one state to another. Resilience is measured in terms of the amount of disturbance the system can absorb before it self-organizes and adopts a new state.

These multiple steady states are better known as 'stability domains'. In the relevant literature they have been represented diagrammatically as basins. A socio-ecological system is represented by a ball that, at its most stable, sits at the bottom of the basin. Stability domains may vary in shape (depth, width) and thus pose more or less of a challenge to stability. A ball (system) that, due to disturbance, moves to the rim of one basin (stability domain) may as easily slide into the next as return to its starting point. These rims are known as 'unstable equilibria', 'thresholds' or 'tipping points'. Resilience is how far you can push the system before it tips into an adjoining stability domain.

Stability domains can change shape. Resilience may be lost if a stability domain shrinks, because the system has less room to move before it meets an instability threshold. A loss of redundancy in a system can also cause a loss of resilience. Biodiversity provides functional redundancy. If one species or subsystem loses resilience, redundancy allows another to keep the system operating as before (Walker, 2008).

The ecological resilience perspective has been adopted in wide-ranging fields including anthropology, environmental psychology, cultural theory, economics, management, and organizational sociology (Folke, 2006: 255). It has particular resonance where social systems and the natural environment interrelate, such as in disaster preparedness and environmental management. Because this article focuses on criminal organizations, we turn now to resilience as applied to organizations.

\section{Organizational resilience}

Resilience has attracted attention in organizational literature and business circles recently due to a growing acknowledgement of the vulnerability of business to threats such as terrorism, natural disasters, cybercrime, accident and employee/management error, neglect or recklessness. Organizational resilience literature assumes that crises (system disturbances) will happen in the natural history of an organization. It focuses on organizational preparedness in terms of strategies, operations and governance structures. Like ecological resilience, organizational resilience generally is taken to go beyond the capacity to withstand disruption to include adaptive capacity: the ability to "turn challenges into opportunities" (Lengnick-Hall and Beck, 2003; see also Seville, 2006). Highly competitive and rapidly changing environments such as today's global markets are especially likely to trigger the need for more than minor adaptation. The "robust transformation" of organizations (Lengnick-Hall and Beck, 2005) is a response to an environmental jolt (in ecological thought, the stimulus for transition between stability domains), such as major technological innovation or political shifts (e.g. deregulation). Organizations that experience such a jolt and find themselves at the "edge of chaos"3 must

\footnotetext{
${ }^{3}$ Complexity theory uses this poetic term to describe the state of turbulence between rigid order and complete chaos where change through self-organization is likely.
} 
make fundamental changes to their objectives and operations in order to survive (Dervitsiotis, 2003). "Resilience capacity" (Lengnick-Hall and Beck, 2003, 2005) enables an organization to develop the necessary routines to make these changes.

Amidst rhetoric about organizational 'flexibility' and 'responsiveness', more specific prescriptions for resilience have been offered. Characteristics of resilient organizations are said to include:

- A “capabilities-based approach" (Oldfield, 2008) (in contrast to a threat identification/risk management approach);

- Strategic/scenario planning (Dervitsiotis, 2003; Seville, 2006);

- Good communication within the organization (Horne, 1997; Horne and Orr, 1998; Oldfield, 2008; Seville, 2006);

- Good communication with key stakeholders (Seville, 2006);

- A shared vision/sense of purpose/set of values (Coutu, 2002; Horne, 1997; Seville, 2006);

- Simple (or "minimal") structures "that regulate without constraining" and afford distributed power (Cunha and Cunha, 2006);

- Inbuilt redundancy, that is, excess capacity (in inventory, production or distribution processes, IT systems or staffing) (Sheffi, 2005);

- Capacity to improvise using available rather than optimal resources (bricolage) (Coutu, 2002; Cunha and Cunha, 2006);

- Inspirational, enthusiastic and intellectually stimulating leaders (Harland et al., 2005; Oldfield, 2008);

- Capacity for effective organizational learning (Zollo and Winter, 2002).

A caveat is required, however. Organizations are not monolithic systems. An organization's resilience will inevitably be influenced by its constituency (Harland et al., 2005; Riolli and Savicki, 2003). It is probably not guaranteed by members' individual resiliency (Horne and Orr, 1998; Riolli and Savicki, 2003), because a complex system is more than the sum of its parts.

\section{Defining resilience}

Drawing on literatures on ecological and organizational resilience, we adopt a concept of resilience that conflates two ideas: the capacity to absorb and thus withstand disruption ${ }^{4}$ and the capacity to adapt, when necessary, to changes arising from that disruption. Adaptation can range from minor evolutionary adjustments through to robust transformations akin to the movement of an ecological system into a new stability domain.

\section{Illegality and resilience}

Most scholarship about organizational resilience pertains only to legitimate business. Can we take the characteristics of resilient organizations listed earlier and simply apply them to criminal organizations?

Differences between licit and illicit organizations have implications for their resilience characteristics. Some of their sources of vulnerability differ. Both types of organization are vulnerable to competition. Both are also under pressure to service the market efficiently, to

\footnotetext{
${ }^{4}$ Bouchard, 2007 refers to this aspect of resilience as 'elasticity'.
} 
satisfy demand and to 'stay ahead of the game' through new product provision and technological improvements. However, the illegality of the products of a criminal organization, such as drugs or extortion, places certain constraints on how it can react to changes in the economic environment compared to a legitimate business (Paoli, 2002). Public advertising is impossible, for one thing, and economies of scale therefore unlikely. Illicit organizations must also operate "without the state" (Paoli, 2002: 64), and cannot access the full range of business tools and strategies, including formal legal processes and institutions for enforcing agreements and arbitrating disputes.

This vulnerability to market forces and the lack of formal dispute resolution mechanisms mean that threats or acts of violence are often used instead to handle non-cooperative collaborators or market-raiding competitors. However, such acts provoke another source of organizational vulnerability, the state. Criminal organizations operate "against the state" (Paoli, 2002: 65) and face a constant risk of interference, member arrest and asset seizure. Unlike competition, the state is a threat with which licit organizations (operating legitimately) need not contend. The existence of this threat requires an "efficiency/security tradeoff" by criminal organizations (Morselli et al., 2007), defined as "the interplay between the need to act collectively and the need to assure trust and secrecy within these risky collaborative settings" (2007: 144). The need for operational secrecy necessarily militates against any kind of resilience deriving from transparent democratic processes.

While dealing in illegal products and having to dodge state bullets increases a criminal organization's vulnerability compared with a legitimate business, sometimes not having to 'play by the rules' may decrease vulnerability. There are no shareholders to report to, no institutions to regulate competition or demand explanations, no media to pry into unethical behaviour. Being an outlaw provides a certain freedom, a lack of accountability that can facilitate operational and structural change.

\section{Gangs as criminal organizations}

Some serious criminal organizations begin life on the streets. As Thrasher (1927/1963: 28) stated, gangs and adult criminal groups tend to "merge into one another by imperceptible gradations". That is not to say that every gang turns into a more serious criminal group. Although gangs cause considerable harm in their local communities, most are ephemeral (Reiss, 1988). In addition, their degree of formal organization is debatable. Many are merely "loose, messy, changing friendship networks" (Robert Ralphs, cited in Davies, 2008) that quickly disband. Others persist, but remain quite disorganized over their lifetimes (Klein and Maxson, 2006). A minority of gangs adopt more serious criminal agendas and cause greater harm, or harm on a wider geographic scale, than a typical neighbourhood gang. The 'supergangs' of North and Central America have provided a model for the institutionalisation of other gangs around the world, such as Black Power and the Mongrel Mob in New Zealand (Hazlehurst, 2007: 140) and some South African gangs (Kinnes, 2000; Standing, 2006). Furthermore, gangs can quickly morph into other types of armed groups and back again (Hagedorn, 2008). The FBI and many other policing organizations are seriously concerned about the potential of gangs to evolve as organized crime threats (Weisel, 2002a: 40-43).

The use of gangs to illustrate the possible sources of resilience for criminal organizations is therefore apt. It is often unclear where the boundary lies between these more organized gangs and other criminal groups. Defining the term 'gang' has challenged researchers since gang research began. The term has been used to cover a spectrum of group types, from nuisance- 
causing groups of juveniles to adults conducting profitable illegal businesses together, such as outlaw motorcycle gangs. Gang characteristics also vary across jurisdictions and cultures (Weerman and Decker, 2005). The shifting nature of gang membership and the difficulties of defining 'organized crime' also contribute to boundary fuzziness.

Links and overlaps between different criminal organizations highlight the permeability and arbitrariness of definitional boundaries. Chinese youth gangs have been associated with U.S. Tongs and Chinese Triads (Broadhurst and King Wa, 2009; Chatterjee, 2006). Some street gangs in London justify their criminal activities by reference to Islamic theology, with members 'radicalized' through extremist contacts in prison (Channel 4, 2008). The PKK in Turkey smuggles drugs to finance its terrorist activities (Mincheva and Gurr 2008), and the organized crime syndicate of the Indian gangster Dawood Ibrahim works with terrorist organizations (Vicziany, 2007). The Bloods gang in New Jersey has reportedly partnered with the Mafia in a prison drug and cell phone smuggling scheme (Chen and Kocieniewski, 2007). In Counties Manakau in New Zealand, youth gang members are recruited by adult gangs for amphetamine trafficking and other criminal activities (Ministry of Social Development, 2006). Despite a variety of labels, it is increasingly difficult to discern any hard and fast demarcations between criminal organizations in our globalized world.

What are the sources of gang resilience? We argue that their resilience characteristics are rooted both in their environments (or "stability domains") and in their unique characteristics, as displayed in organizational structures and operational strategies.

\section{Gang environments}

Three environmental sources of gang resilience can be identified: thick crime habitats; community support; and a high level of interpenetration between gangs and legitimate businesses and state authorities.

\subsection{Thick crime habitats}

The concept of a crime habitat is one aspect of the 'crime ecosystem' proposed by Felson (2006: 61). A thick crime habitat contains a multitude of settings for crime and is rich in crime targets (2006: 231ff.). Thick crime habitats are conducive to resilience because they continually generate new criminal opportunities for the gang and also provide the space to self-organize to take advantage of them. These spaces include both 'offender convergence settings' (2006: 98-99) where offenders can share information, find co-offenders and make plans, and places to go to recover from setbacks, such as arrest or injury of members. Thick crime habitats are plentiful in (although not necessarily limited to) large urban conglomerates, particularly in weak or failing states.

A thick crime habitat is also likely to host many criminal groups that find the environment conducive to business. Contact between organizations can lead to a form of organizational learning known as "modelling" (Braithwaite and Drahos, 2000: 25). Gang members may learn the methodologies and philosophies of more experienced criminals and use them as role models. Because of modelling, institutions of incarceration have proved fruitful incubators of gangs and other criminal groups (Fleisher and Decker, 2001; Hagedorn, 2005, 2008; Hazlehurst, 2007; Kelly and Caputo, 2005).

Knowledge and skills learnt from other groups provide a potent tool for environmental adaptation, as do strategic alliances between groups (Williams, 1995). Affiliation with adult 
gangs may well explain the resilience of some criminal youth gangs in New Zealand, such as the Auckland Killer Beez, a feeder gang for the Tribesmen motorcycle gang that within six years has substantially expanded its methamphetamine trafficking and vehicle crime despite several police operations and considerable competition (Ministry of Social Development, 2006; Gower, 2008).

\subsection{Community support}

Gangs often have multilayered relationships with their communities, with community members not only keen for gang activity to cease but also non-judgmental about individual gang members, who many regard as victims of the 'system' (Aldridge and Medina, 2008). Sometimes however, instead of promoting efforts to disband gangs, communities support the gang as an institution. This can have a basis in community traditions (Sánchez-Jankowski, 1991; Spergel et al., 1994), or stem from benefits the gang bestows. In Jamaica, for instance, some communities support their local gang because it 'returns the spoils' of crime to them (Williams, 2008). Some larger gangs in the United States have assisted residents with accommodation and bills, protected them from physical attack and exploitation, organized recreational activities and otherwise contributed to community well-being (Sánchez-Jankowski, 1991; Venkatesh, 1997, 2006). Community support may also be based in the "ghetto" reputation gangs give an area that keeps local rents low and the forces of gentrification at bay (Katz and Jackson-Jacobs, 2004). The relationship between gangs and communities has been described as a 'working relationship' or 'social contract' (Sánchez-Jankowski, 1991), but a personal component often exists too. Residents may refuse to ostracize gang members because they are their own, relatives' and friends' children, and sometimes their employees (Venkatesh, 1997).

This kind of community support, even when half-hearted, is clearly a source of resilience for the gang. It gives members a sanctuary, a place to regroup and reorganize after disruption, and provides material and psychological resources for that process.

\subsection{Degree of interpenetration}

No gang or other criminal organization is a stand-alone system. All have a close relationship with the licit world (Morselli and Giguère, 2006; Spergel et al., 1994; Williams, 1995, 2001). Relationships between organized crime groups and the state are "more often symbiotic and clientelistic than confrontational" (Council of Europe, 2005: 20). ${ }^{5}$ Criminal enterprises may both sponsor the state and have its patronage, making it difficult to regard them as unequivocally opposed to the state (Findlay, 2007).

Collusion with authorities also marks the life passage of many gangs. Hagedorn (2005, 2007) notes that nineteenth century gangs in the United States were used by politicians for many purposes: Irish 'voting gangs' for intimidation of political rivals; white gangs for enforcing the racial order. In return, politicians sponsored gang 'social athletic clubs' and paid their rents, occasionally moderated police harassment and sometimes provided jobs for members leaving gangs. In China in 1927, a triad gang, the Green Circle, assisted the ruling Kuomintang to massacre communists (Hagedorn, 2005). In places as diverse as Jamaica, India

\footnotetext{
${ }^{5}$ Morselli and Giguère (2006) argue that legitimate actors are not just 'orchestrated' by criminals, but play a positive role in structuring criminal networks through providing services and facilitating their operations. Legitimate industries also influence criminal opportunity structures.
} 
and South America, gangs today still actively support particular political factions (Hagedorn, 2005, 2008; McCann, 2006).

The businesses of gangs and legitimate firms may also be entangled. Legitimate businesses both aid gangs and are assisted by them (such as when a nightclub relies on a gang for security services, overlooking in return its drug dealing on the premises). In addition, some gangs, such as the Gangster Disciples in Chicago, have extensive investments in legitimate businesses (Decker et al., 1998). Making such investments requires facilitation by the licit world.

Like a complex web of roots that thwart attempts to remove a tree, the commensal associations at both member and group levels between gangs and legitimate businesses and state authorities provide a source of gang resilience to disturbance.

\section{Gang characteristics}

Gang resilience is also to be found in characteristics peculiar to a gang itself, such as its structure and operational methods.

\subsection{Semi-structures, empowered members and shared vision}

The organizational resilience literature suggests that the structure that best assures an organization's survival and adaptability in a turbulent market environment is one that responds efficiently to signals of imminent change. The most efficient structures are simple ones that "regulate without constraining" (Cunha and Cunha, 2006: 842). Brown and Eisenhardt (1997: 28) dub these organizational forms "semi-structures", because they "lie between the extremes of very rigid and highly chaotic organization".

Simple structures are flatter or minimally hierarchical, and decision-making power is therefore more equally distributed throughout the organization. As a result "(e)mpowered employees may respond quicker to challenges simply because they have not to wait for others (and for orders) to take action" (Cunha and Cunha, 2006: 843). To balance this flexibility in the semi-structure, a clear and shared vision, purpose or set of values is necessary so that empowered actors serve central strategic objectives rather than their own agendas (Dervitsiotis, 2003: 264).

This prescription for resilience - flattish structures, empowered members and a clear shared purpose or set of values - as readily applies to criminal organizations as to legitimate ones. Indeed, resilient gangs appear almost innately semi-structural, given both their origins in spontaneous assemblages of youths that predispose them to chaos and the pursuit of individual freedoms, and their need for a degree of organization for gang protection. Increasing levels of organization have been observed in more resilient gangs (Decker et al., 1998; Weisel, 2002b). Differentiated membership levels, leadership roles, regular meetings, written rules and a 'distinct outlook' reflected in rituals and symbols have been identified as some of the indicators of a gang's institutionalisation (Decker et al., 2008; Hagedorn, 2008). Such organizational constraints on individual freedoms provide "the coordination mechanisms necessary to assure a common purpose" (Cunha and Cunha, 2006: 842). But if a gang's structure becomes too complex or bureaucratic, adaptation to changing conditions will become more difficult (Weisel, 2002b).

\subsection{Redundancy}

The importance of redundancy through diversity for ensuring the resilience of both ecological systems and corporations has been noted earlier. Redundancy in the form of a diversity of ties 
between actors is also a characteristic of resilient criminal organizations (Williams, 2001). A network replete with redundant ties will have less difficulty adapting to the removal of actors through the actions of competitors or police. Institutionalised gangs tend to ensure redundancy by maintaining a generalist orientation and little role differentiation between members (Weisel, 2002b: 187), but other criminal organizations may recruit specifically for this purpose.

\subsection{Network architecture: hubs, weak links and loose coupling}

The way a gang is structured therefore matters. The need to incorporate redundancy does not necessarily imply that a gang network must be large to be resilient. Stohl and Stohl (2007, writing about terrorist networks) suggest the opposite: an architecture in which highly clustered segments or hubs displaying strong links between actors and a high level of redundancy are connected to each other by weak links (Granovetter, 1973) or 'loose coupling' reduces immensely the number of links required to connect up the whole system. A simpler structure like this may be more resistant to random attacks on nodes/hubs.

The tightness of 'coupling' between links is a concept derived from organizational studies and computing. 'Loose coupling' indicates that very little reliance is placed by one node on the other. Williams (2001: 80) suggests that loose coupling in a criminal network will increase its resilience, because "knock-on or cascading effects are limited and damage to one part of the network does not undermine the network as a whole". By analogy, a strike would be more difficult to bowl if the bowling balls were joined by slack strings rather than taut ones.

Some of the larger American gangs such as MS-13, the Crips and the Bloods, appear to be structured as networks of hubs, constituted by gang chapters, sets or cliques in different locations (including prisons), connected by loose couplings. Within hubs, however, ties are likely to be tight and strong, due to both the need for organizational constraints on individual actions (as discussed earlier) and a collective defiant response to external interventions that firms up gang cohesiveness (Klein and Maxson, 2006). The social history of the gang and its members also affects the nature of ties.

\subsection{History and the nature of ties}

Ties between actors in a network are not just for information relay: they are also "sites of sense making and socialization that reinforce ways of seeing the world and provide sources of role models and inspiration" (Stohl and Stohl, 2007: 100). In other words, ties have a qualitative and dynamic character. They arise out of social histories that explain how the organization/network emerged and is likely to develop (Stohl and Stohl, 2007). Similar patterns of ties between actors may therefore have different behavioural consequences. Both the content of ties and the organization's history are significant for predicting how an organization is likely to cope with change.

The social histories of many gangs reveal their origins in immigrant groups, where alienation has promoted an emphasis on tradition and family. In these circumstances, ethnic and cultural commonalities, as well as shared experiences of deprivation and discrimination, provide the glue to band youths together. As von Lampe and Johansen (2003: 12) note, "ethnic communities will tend to be characterized by a strong sense of "we and they"'. Kinship ties between gang members are also prevalent. Kinship and ethnicity provide one basis for trust (von Lampe and Johansen, 2003). As in the kinship webs of the Zealots (Matusitz, 2008), strong trust between members speeds information flow through a gang, making possible lightning adjustments to game plans and facilitating more measured debate about longer-term adjustments. 
However, close relationships may also increase the vulnerability of an organization should there be an information leak.

\subsection{Secrecy and compartmentalisation}

Trust may be grounded not in close social ties but in criminal reputations, or in the expectation of shared values with members of the same deviant subculture. Moreover, criminal cooperation can also occur in the absence of trust or between mistrusting network participants (von Lampe and Johansen, 2003).

The loose couplings linking cohesive hubs have clear benefits for criminal networks but also present security risks, in the form of a larger pool of potential informants (Jones, 2006). Nevertheless, for efficiency's sake, and even absent trust, there remains the need to engage in partnerships (between these hubs or with other organizations). In terms of an 'efficiency/ security tradeoff', if little trust exists, security of information becomes the priority. Security is often achieved through 'compartmentalisation', the isolation of important information within certain organizational 'cells' (Kenney, 2007; Williams, 2001). Compartmentalisation effectively insulates parts of the network from damage wreaked on other parts, allowing fast and adaptive regeneration of network operations (in cells containing the requisite knowledge) following attacks by law enforcement. One kind of information a gang may compartmentalise is the identity of leaders and others filling crucial roles.

\subsection{Leadership}

Despite eighty years of gang studies, little research had been done on leadership in gangs. Gang leadership is a somewhat fluid concept. Types of leaders vary between gangs and across locations. Frequent changes of gang leader and different leaders for distinct gang activities are not uncommon, and gang leadership may be "more a function of individual prowess and reputation than a formalized structure for making collective decisions" (FBI's Criminal Investigation Division, quoted in Weisel, 2002a: 41). Yet the increasing systemisation of activities observed in larger gangs suggests that leadership is necessary for coordination of the institutionalisation process and that leaders are influential in decisions that allow gangs to grow and adapt. From the existing research, Schneider (2001) concludes that, without leaders to provide continuity and to mentor younger members, gangs are unlikely to thrive.

Gang resilience may in part be a function of leaders' personal attributes and how these influence their decisions and leadership styles. Despite years of 'trait theory' research, there is little indication that successful leaders share a particular set of traits (Vickers and Kouzmin, 2001). Clearly, a leader's influence on resilience could be either positive or negative. A leader's ideology and temperament, for example, may affect the choices made between violent or peaceful conflict resolution, thus influencing individual and gang longevity. The conversion to Islam of Black P Stone Nation (BPSN) leader, Jeff Fort, led to the Chicago BPSN changing its name to El Rukns and the subsequent involvement of gang members in and their imprisonment for a conspiracy to commit terrorist acts as mercenaries for al-Qadhafi.

Different leadership styles may have variable consequences. Participative leadership styles are thought to heighten creativity within an organization, and authoritarian styles to diminish it (Woodman et al., 1993). Flatter structures are more likely to exhibit participative decisionmaking and flexible leadership styles, and thus more creativity, than bureaucratic or hierarchical 
structures. Weisel (2002b) found participative decision-making mechanisms in all four of the large institutionalised U.S. gangs she studied.

\subsection{Bricolage}

Bricolage is an ability to take available resources, even if seemingly unconnected, and make something new from them. Gangs, like legitimate organizations, need skills of bricolage in order to respond creatively to environmental change and hostile interventions. Creativity is facilitated by flatter structures because information flows more readily through them. Information constitutes the resources for a strategy-focused bricolage and is comprised of both new information and stored experiential knowledge.

Where an organization imposes constraints on information flow to minimize risks to its survival, its creativity may decrease (Kenney, 2006; Woodman et al., 1993). Accordingly, to maximise resilience, criminal organizations need to find the appropriate balance between selfprotection through secrecy and a free flow of information and know-how so that members can think creatively about embracing or generating change.

\subsection{Organizational learning}

How might a gang ensure that its members are properly informed and have the skills to adapt to change? Criminal organizations learn in the same ways legitimate organizations do, but face additional challenges. Zollo and Winter (2002) suggest that organizational learning takes place in three ways: experience accumulation (learning by doing); deliberate knowledge articulation; and knowledge codification.

Through being faced by challenges and overcoming them, organizations learn what works and what doesn't. Experience shapes new operating routines, and also the development of procedures for changing those routines: "[i]n short, organizations learn to change by changing" (Amburgey et al., 1993: 54). Drug trafficking organizations, for example, often tinker with their routes and methods of drug transportation in order to keep one step ahead of law enforcement.

Much of the knowledge articulation within criminal organizations happens informally in the course of social interactions (Kenney, 2007). Gangs mostly disseminate and gather knowledge in this way. But learning may also take place more formally, through meetings, training sessions, fact finding 'missions' (as with the Colombian drug traffickers Kenney studied), outside consultants, the use of technology, and contacts with other organizations. Strategic alliances between criminals allow synergies to develop and "strategic gaps" in resource availability to close (Williams, 1995). Over time, some harmonisation of practices and ideas between organizations might even take place through observation and modelling.

Codification of knowledge is de rigeur in and often legally required of legitimate organizations, but for criminal organizations, documentation may disclose its shady practices and plans, so codification tends to be minimized. This poses problems for organizational memory, as mental records are "more likely to be forgotten, manipulated, or subject to faulty recall" (Kenney, 2006: 157), and are difficult to disseminate widely, particularly across loose networks. However, because tacit knowledge or 'know-how' cannot be easily replicated, its diffusion is especially important. Organizational memory is key to learning, as it enables retrieval of the lessons of history despite personnel changes and avoids the need to reinvent the wheel.

Compartmentalisation of information also handicaps learning by creating barriers to information flows (Jackson, 2006; Kenney, 2007). One hub or cell may end up repeating 
another's mistakes. Other impediments to learning include competency traps (use of familiar rather than new routines or technologies for reasons of efficiency) (Jackson, 2006), imperfect information, individual biases and blind spots, and the constraints of internal politics (Kenney, 2006).

Effective learning for any organization is fraught, but is especially so for criminal organizations needing to disseminate knowledge efficiently whilst limiting access to certain information. The resilient criminal organization masters learning and knowledge diffusion without compromising security.

\section{Conclusion}

Some gangs last and may be "nearly invulnerable to repression" (Hagedorn, 2008: 10). This is small comfort for the communities that must still cope with their everyday troublesome presence. Drawing on theories of ecological and organizational resilience, this article develops a resilience approach to the longevity of some criminal organizations. Developing new approaches that help us to understand the survivability of criminal organizations is important for many reasons, including cost. For example, serious organized crime is estimated to cost Australia in excess of $\$ 10$ billion annually (Australian Crime Commission, 2009).

A resilience perspective provides a fresh approach to designing strategies to minimize the damaging impacts of criminal organizations and highlights that there are many sites of possible intervention. For police organizations, thinking about resilience suggests several strategic and operational pathways.

Strategically, a resilience perspective calls for an ecological approach to intelligence gathering. Because every criminal organization is a unique and changing system sited within and influenced by its particular evolving stability domain, extensive intelligence is required on a continuing basis. A 'snapshot' of an organization at one time will clearly not be a sufficient basis for crafting interventions for all time.

Second, a resilience perspective confirms the findings of a number of gang researchers (see Klein and Maxson, 2006; Decker et al., 2008) that interventions risk having unintended consequences. Rather than decrease an organization's resilience, law enforcement action might stimulate an organizational adaptation that is more resilient and perhaps more harmful. Particularly unstable organizations such as gangs, for example, may 'robustly transform' or 'tip' into a new stability domain, altering their character, objectives, ideology or activities. An assessment of this risk can only be made on the basis of the most current intelligence available. In some instances, it may be wiser not to intervene.

Where intervention by the state is considered appropriate, a resilience perspective could contribute to operational planning. Reducing a gang's resilience may be achieved through shrinking its stability domain. For example, offender convergence settings might be identified and eliminated, and community support for a gang reduced by effectively addressing the community's financial and social needs through partnerships between law enforcement and other agencies. Similarly, an organization's internal sources of resilience could be identified and creative responses forged. Skills of bricolage residing in certain gang members and currently directed to gang adaptation, for example, might be encouraged and redirected into legitimate employment. For instance, gang members adept at car rebirthing might be trained as mechanics. Careful analysis of gang structures may facilitate the targeting of close member relationships for covert interference or of loose couplings for further weakening. Disruption of gang learning processes may be attempted. 
More research on resilience is clearly desirable. In particular, empirical studies of individual criminal organizations, identifying their sources of resilience and how these work to ensure their growth and survival in practice, would provide a basis for more targeted strategic and operational approaches by law enforcement. Clearly, in order to test theory and sharpen its usefulness, such studies would be best conducted through cooperative arrangements between practitioners and academics.

\section{Acknowledgments}

This work was supported by the Australian Research Council Centre of Excellence in Policing and Security. Many thanks to Professors Peter Drahos, Peter Grabosky and Michael Stohl and an anonymous reviewer for their helpful comments on earlier drafts.

\section{References}

Aldridge, J., Medina, J., 2008. Youth Gangs in an English City: social exclusion, drugs and violence. Research Report ESRC RES-000-23-0615, 16 January.

Amburgey, T.L., Kelly, D., Barnett, W., 1993. Resetting the clock: the dynamics of organizational change and failure. Administrative Science Quarterly 38 (1), 51-73.

Australian Crime Commission, 2009. Organised crime in Australia. Available at: http://www.crimecommission.gov.au/ organised_crime/index.htm (accessed 20.10.09).

Bouchard, M., 2007. On the resilience of illegal drug markets. Global Crime 8 (4), 325-344.

Braithwaite, J., Drahos, P., 2000. Global Business Regulation. Cambridge University Press, Cambridge.

Broadhurst, R., King Wa, L., 2009. The Transformation of Triad 'Dark Societies' in Hong Kong: the impact of law enforcement, socio-economic and political change. Security Challenges 5 (4).

Brown, S.L., Eisenhardt, K.M., 1997. The art of continuous change: linking complexity theory and time-paced evolution in relentlessly shifting organizations. Administrative Science Quarterly 42 (1), 1-34.

Channel 4, 2008. Dispatches: from Jail to Jihad, 16 June. Available at: http://www.videosift.com:80/video/DispatchesFrom-Jail-to-Jihad (accessed 01.10.08).

Chatterjee, J., 2006. A Research Report on Youth Gangs: Problems, Perspective and Priorities. Royal Canadian Mounted Police, Ottawa.

Chen, D.W., Kocieniewski, D., 19 December 2007. 'Alarming Alliance' of Mafia and Street Gang is broken up. The New York Times.

Council of Europe, 2005. Organized Crime Situation Report 2005: Focus on the Threat of Economic Crime. Council of Europe, Strasbourg.

Coutu, D.L., 2002. How resilience works. Harvard Business Review May.

Cunha, M. Pina e, Cunha, J. Viera da, 2006. Towards a complexity theory of strategy. Management Decision 44 (7), 839-850.

Davies, N., 14 July 2008. Youth violence: tactics against gangs fatally flawed - report. The Guardian.

Decker, S.H., Bynum, T., Weisel, D., 1998. A tale of two cities: gangs as organized crime groups. Justice Quarterly 15 (3), 395-425.

Decker, S.H., Katz, C.M., Webb, V.J., 2008. Understanding the black box of gang organization: implications for involvement in violent crime, drug sales, and violent victimization. Crime and Delinquency 54 (1), $153-172$.

Dervitsiotis, K., 2003. The pursuit of sustainable business excellence: guiding transformation for effective organizational change. Total Quality Management \& Business Excellence 14 (3), 251-267.

Felson, M., 2006. Crime and Nature. Sage, Thousand Oaks, CA.

Findlay, M., 2007. Global terror and organized crime: symbiotic or synonymous? In: Organized Crime In Asia: Governance and Accountability, Proceedings of the Symposium, June, Queensland University of Technology. QUT Digital Repository Available at: http://eprints.qut.edu.au (accessed 23.4.09).

Fleisher, M.S., Decker, S.H., 2001. An overview of the challenge of prison gangs. Corrections Management Quarterly 5 (1), 1-9.

Folke, C., 2006. Resilience: the emergence of a perspective for social-ecological systems analyses. Global Environmental Change 16, 253-267.

Gower, P., 19 January 2008. Gang presence growing since early days in Otara. New Zealand Herald.

Granovetter, M.S., 1973. The strength of weak ties. American Journal of Sociology 78 (6), 1360-1380. 
Gunderson, L.H., 2000. Ecological resilience - in theory and application. Annual Review of Ecology and Systematics $31,425-439$.

Hagedorn, J.M., 2005. Gangs and politics. In: Sherrod, L.R. (Ed.), Youth Activism: An International Encyclopedia. Greenwood Press, Westport CT.

Hagedorn, J.M., 2007. Gangs in late modernity. In: Hagedorn, J.M. (Ed.), Gangs in the Global City: Alternatives to Traditional Criminology. University of Illinois Press, Champaign IL.

Hagedorn, J.M., 2008. A World of Gangs: Armed Young Men and Gangsta Culture. University of Minnesota Press, Minneapolis MN.

Harland, L., Harrison, W., Jones, J.R., Reiter-Palmon, R., 2005. Leadership behaviors and subordinate resilience. Journal of Leadership and Organizational Studies 11 (2), 2-14.

Hazlehurst, C., 2007. Observing New Zealand "Gangs", 1950-2000: learning from a small country. In: Hagedorn, J.M. (Ed.), Gangs in the Global City: Alternatives to Traditional Criminology. University of Illinois Press, Champaign IL.

Holling, C.S., 1961. Principles of insect predation. Annual Review of Entomology 6, 163-182.

Horne, J.F., 1997. The coming age of organizational resilience. Business Forum 22 (2/3), 24-28.

Horne, J.F., Orr, J.E., 1998. Assessing behaviors that create resilient organizations. Employment Relations Today 24, 29-39.

Jackson, B.A., 2006. Organizational learning and terrorist groups. In: Brown, M.L., Kenney, M., Zarkin, M. (Eds.), Organizational Learning in the Global Context. Ashgate, Aldershot UK.

Jones, C., 2006. Al-Qaeda's innovative improvisers: learning in a diffuse transnational network. Cambridge Review of International Affairs 19 (4), 555-569.

Katz, J., Jackson-Jacobs, C., 2004. The criminologists' gang. In: Sumner, C. (Ed.), The Blackwell Companion to Criminology. Blackwell, London.

Kelly, K., Caputo, T., 2005. The linkages between street gangs and organized crime: the Canadian experience. Journal of Gang Research 13 (1), 17-31.

Kenney, M., 2006. Organizational learning processes in Colombian drug trafficking networks. In: Brown, M.L., Kenney, M., Zarkin, M. (Eds.), Organizational Learning in the Global Context. Ashgate, Aldershot UK.

Kenney, M., 2007. From Pablo to Osama: Trafficking and Terrorist Networks, Government Bureaucracies and Competitive Adaptation. Pennsylvania State University Press, University Park, PA.

Kinnes, I., 2000. From Urban Street Gangs to Criminal Empires: The Changing Face of Gangs in the Western Cape. Monograph No 48, June. Institute for Security Studies, Pretoria.

Klein, M.W., Maxson, C.L., 2006. Street Gang Patterns and Policies. Oxford University Press, New York.

Lengnick-Hall, C.A., Beck, T.E., 2003 Beyond Bouncing Back: The Concept of Organizational Resilience. Paper presented at the National Academy of Management meetings, Seattle, WA.

Lengnick-Hall, C.A., Beck, T.E., 2005. Adaptive fit versus robust transformation: how organizations respond to environmental change. Journal of Management 31 (5), 738-757.

Matusitz, J., 2008. Similarities between terrorist networks in antiquity and present-day cyberterrorist networks. Trends in Organized Crime 11, 183-199.

McCann, B., 2006. The political evolution of Rio De Janeiro's Favelas. Latin American Research Review 41 (3), $149-163$.

Mincheva, L., Gurr, T.R., 2008. Unholy Alliances III: Communal Militants and Criminal Networks in the Middle East, with a Case Study of the Kurdistan Workers Party (PKK). Paper presented at the Annual Meeting of the International Studies Association, San Francisco, 28 March.

Ministry of Social Development, 2006. From Wannabes to Youth Offenders: Youth Gangs in Counties Manakau. Research Report. The Ministry of Social Development, Wellington, NZ.

Morselli, C., Giguère, C., 2006. Legitimate strengths in criminal networks. Crime, Law and Social Change 45, $185-200$.

Morselli, C., Giguère, C., Petit, K., 2007. The efficiency/security trade-off in criminal networks. Social Networks 29 , $143-153$.

Nohria, N., 1992. Is a network perspective a useful way of studying organizations? In: Nohria, N., Eccles, R.G. (Eds.), Networks and Organizations: Structure, Form, and Action. Harvard Business School Press, Boston, MA.

Norris, F.H., Stevens, S.P., Pfefferbaum, B., Wyche, K.F., Pfefferbaum, R.L., 2008. Community resilience as a metaphor, theory, set of capacities, and strategy for disaster readiness. American Journal of Community Psychology 41, $127-150$.

Oldfield, R., 2008. Organizational resilience. Presentation to the Business Continuity Institute NSW Forum Meeting, March. Available at: http://www.thebci.org.au/NSW\%20Resilience\%20Mar\%2008.pdf (accessed 7.08.08).

Paoli, L., 2002. The paradoxes of organized crime. Crime, Law and Social Change 37, 51-97. 
Reiss Jr., A.J., 1988. Co-offending and criminal careers. Crime and Justice 10, 117-170.

Riolli, L., Savicki, V., 2003. Information system organizational resilience. Omega 31 (3), 227-233.

Sánchez-Jankowski, M., 1991. Islands in the Street: Gangs and American Urban Society. University of California Press, Berkeley CA.

Schneider, J.L., 2001. Niche crime: the Columbus gangs study. American Journal of Criminal Justice 26 (1), $93-105$.

Seville, E., 2006. Resilience: what does it mean for an organization? CAE Information Bulletin 35 (March), 6-7.

Sheffi, Y., 2005. The Resilient Enterprise: Overcoming Vulnerability for Competitive Advantage. Massachusetts Institute of Technology, Cambridge MA.

Spergel, I., Curry, D., Chance, R., Kane, C., Ross, R., Alexander, A., Simmons, E., Oh, S., 1994. Gang Suppression and Intervention: Problem and Response: Research Summary. Office of Juvenile Justice and Delinquency Prevention, Washington DC.

Standing, A., 2006. Organized Crime: A Study from the Cape Flats. Institute for Security Studies, Pretoria.

Stohl, C., Stohl, M., 2007. Networks of terror: theoretical assumptions and pragmatic consequences. Communication Theory $17,93-124$.

Templeman, D., Bergin, A., 2008. Taking a Punch: Building a More Resilient Australia. Strategic Insights. Australian Strategic Policy Institute, Canberra.

Thrasher, F.M., 1927/1963. The Gang: A Study of 1,313 Gangs in Chicago, Abridged Edition with Introduction by J.F. Short. The University of Chicago Press, Chicago and London.

Venkatesh, S.A., 1997. The social organization of street gang activity in an urban ghetto. American Journal of Sociology 103 (1), 82-111.

Venkatesh, S.A., 2006. Off The Books: The Underground Economy of the Urban Poor. Harvard University Press, Cambridge MA.

Vickers, M.H., Kouzmin, A., 2001. 'Resilience' in organizational actors and rearticulating 'voice': towards a humanistic critique of new public management. Public Management Review 3 (1), 95-119.

Vicziany, M., 2007. Understanding the 1993 Mumbai Bombings: Madrasses and the Hierarchy of Terror. South Asia: Journal of South Asian Studies XXX (1), 43-73.

von Lampe, K., Johansen, P.O., 2003. Criminal Networks and Trust. Paper presented at the Third Annual Meeting of the European Society of Criminology, Helsinki, 29 August.

Walker, B., Holling, C.S., Carpenter, S.R., Kinzig, A., 2004. Resilience, adaptability and transformability in socialecological systems. Ecology and Society 9 (2), 5. (online) URL: http://www.ecologyandsociety.org/vol9/iss2/art5/.

Walker, B.H., 31 May 2008. A Resilience Approach to an Uncertain Future. Lecture to the Combined Academies. Australian National University.

Weerman, F.M., Decker, S.H., 2005. European Street Gangs and Troublesome Youth Groups: findings from the Eurogang Research Program. In: Decker, S.H., Weerman, F.M. (Eds.), European Street Gangs and Troublesome Youth Groups. AltaMira Press, Lanham MD.

Weisel, D.L., 2002a. The evolution of street gangs: an examination of form and variety. In: Reed, W.L., Decker, S.H. (Eds.), Responding to Gangs: Evaluation and Research.NCJ 190351. National Institute of Justice, Washington DC.

Weisel, D.L., 2002b. Contemporary Gangs: An Organizational Analysis. LFB Scholarly Publishing, New York.

Williams, P., 1995. Transnational criminal organizations: strategic alliances. Washington Quarterly 18 (1), 57-72.

Williams, P., 2001. Transnational criminal networks. In: Arquilla, J., Ronfeldt, D. (Eds.), Networks and Netwars: The Future of Terror, Crime and Militancy. RAND, Santa Monica, CA.

Williams, P., 27 July 2008. Want to rid Ja of gangs? The Jamaica Observer.

Woodman, R.W., Sawyer, J.E., Griffin, R.W., 1993. Toward a theory of organizational creativity. The Academy of Management Review 18 (2), 293-321.

Zollo, M., Winter, S.G., 2002. Deliberate learning and the evolution of dynamic capabilities. Organization Science 13 (3), 339-351.

Julie Ayling is an Associate Investigator in the Australian Research Council Centre of Excellence in Policing and Security, based in the Regulatory Institutions Network at the Australian National University. She is author of Lengthening the Arm of the Law: Enhancing Police Resources in the 21st Century (with Peter Grabosky and Clifford Shearing), Cambridge University Press, 2009. 